\title{
Impacts of NF1 Gene Mutations and Genetic Modifiers in Neurofibromatosis Type 1
}

\author{
Wei Wang ${ }^{\dagger}$, Cheng-Jiang Wei ${ }^{\dagger}$, Xi-Wei Cui ${ }^{\dagger}$, Yue-Hua Li, Yi-Hui Gu, Bin Gu, Qing-Feng Li ${ }^{*}$ \\ and Zhi-Chao Wang *
}

Department of Plastic and Reconstructive Surgery, Shanghai Ninth People's Hospital, Shanghai Jiao Tong University School of Medicine, Shanghai, China

Neurofibromatosis type 1 (NF1) is a tumor predisposition genetic disorder that directly affects more than 1 in 3,000 individuals worldwide. It results from mutations of the NF1 gene and shows almost complete penetrance. NF1 patients show high phenotypic variabilities, including cafe-au-lait macules, freckling, or other neoplastic or non-neoplastic features. Understanding the underlying mechanisms of the diversities of clinical symptoms might contribute to the development of personalized healthcare for NF1 patients. Currently, studies have shown that the different types of mutations in the NF1 gene might correlate with this phenomenon. In addition, genetic modifiers are responsible for the different clinical features. In this review, we summarize different genetic mutations of the NF1 gene and related genetic modifiers. More importantly, we focus on the genotype-phenotype correlation. This review suggests a novel aspect to explain the underlying mechanisms of phenotypic heterogeneity of NF1 and provides suggestions for possible novel therapeutic targets to prevent or delay the onset and development of different manifestations of NF1.

Keywords: neurofibromatosis type 1, genotype-phenotype correlation, modifier genes, NF1 gene, clinical
variability

tThese authors have contributed equally to this work and share first authorship

Specialty section:

This article was submitted to Neuro-Oncology and Neurosurgical Oncology,

a section of the journal Frontiers in Neurology

Received: 03 May 2021 Accepted: 15 July 2021 Published: 08 September 2021

Citation:

Wang W, Wei C-J, Cui X-W, Li Y-H, Gu Y-H, Gu B, Li Q-F and Wang Z-C (2021) Impacts of NF1 Gene Mutations and Genetic Modifiers in Neurofibromatosis Type 1. Front. Neurol. 12:704639. doi: 10.3389/fneur.2021.704639

\section{INTRODUCTION}

Neurofibromatosis type 1 (NF1), a relatively common tumor predisposition genetic disorder, affects $\sim 1: 3,000-3,500$ live births worldwide (1). NF1 patients present lifelong phenotypic variability with almost complete penetrance (Figure 1). Common clinical NF1-related manifestations based on the NIH diagnosis criteria include multiple cafe-au-lait macules (CALMs), Lisch nodules, cutaneous/dermal neurofibromas (CNFs), plexiform neurofibromas (PNFs), and osseous defects (2). Other distinctive features such as learning disability and childhood overgrowth are also reported (3). Neoplastic complications are also associated with NF1 and greatly affect life quality, including malignant peripheral nerve sheath tumor (MPNST), optic glioma, leukemia, and breast cancer (4-7). Clinical expressivity among NF1 patients is variable, unpredictable, and age-related. Exploration of the underlying mechanisms of these variabilities is important for further personalized healthcare and makes prognostic counseling easier (8).

Studies showed that both the NF1 mutations and modifiers may correlate with the variations in clinical phenotype. Genotype-phenotype relationships provide an approach to understand the pathogenesis and development of NF1. On the one hand, NF1 is a genetic disorder resulting from mutations in the NF1 gene. This gene, located on chromosome 17, band q11.2, is a large 


\section{Germline mutations}

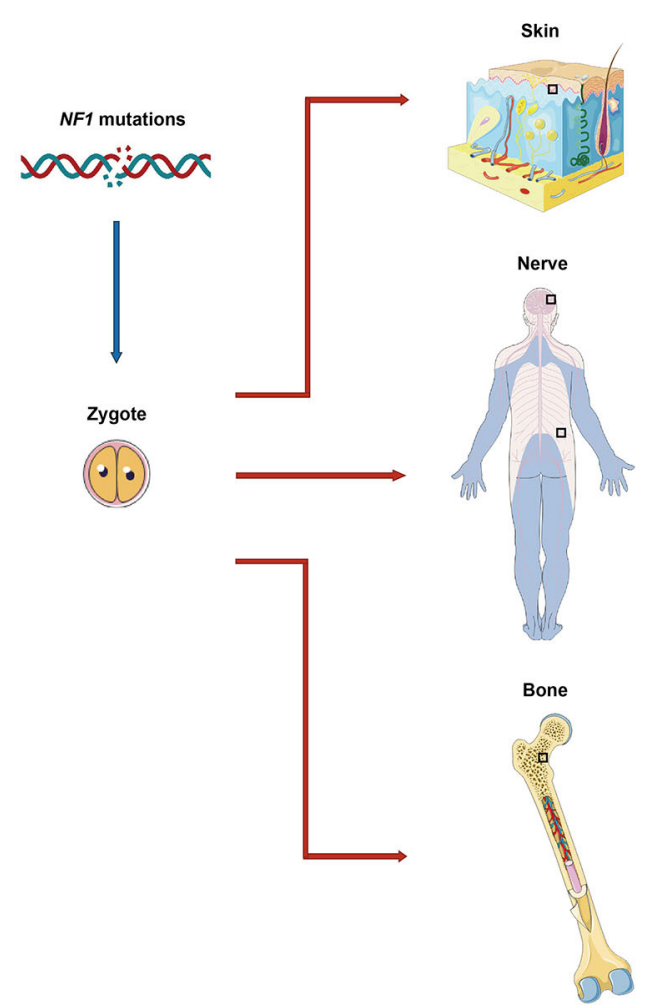

\section{Affected systems}
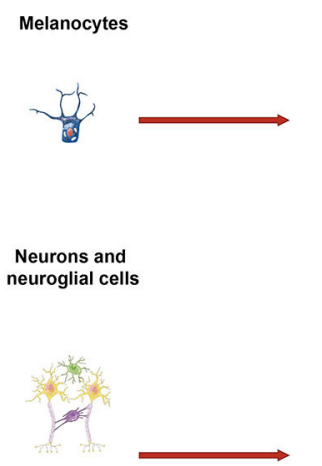

Bone cells

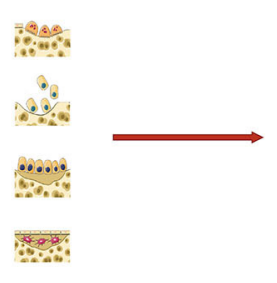

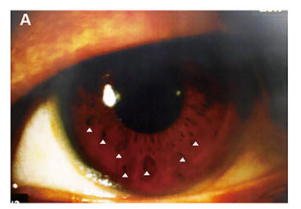
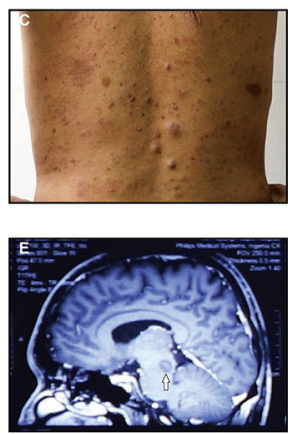

Related phenotypes
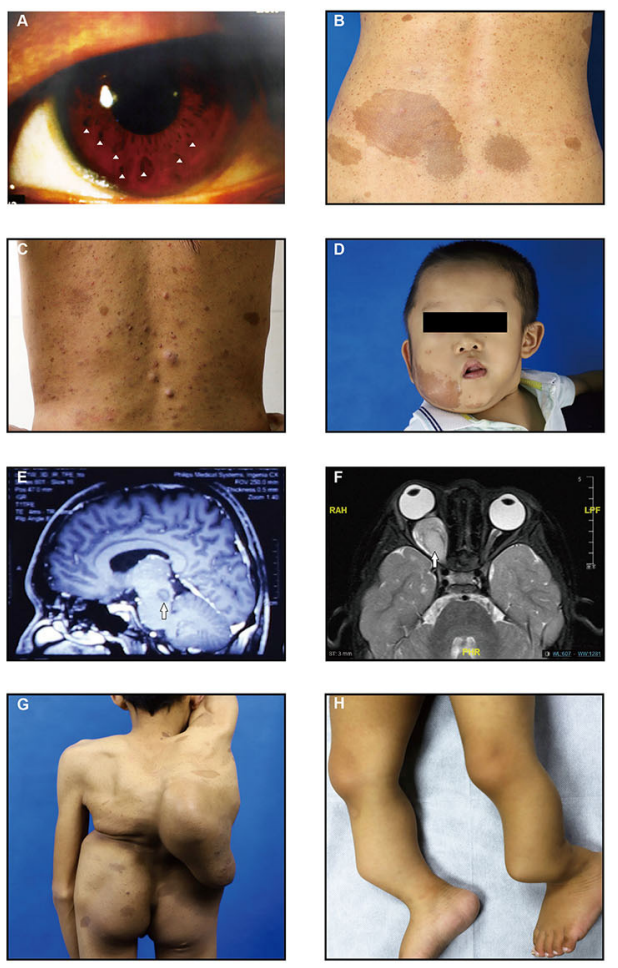

FIGURE 1 | Common affected systems and related phenotypes in neurofibromatosis type 1 (NF1) patients. Diverse clinical features present due to the NF1 gene mutations in different cell types including melanocytes, neurons, neuroglial cells, osteoblasts, etc. (A) Lisch nodules, (B) cafe-au-lait macules, (C) cutaneous neurofibromas, (D) plexiform neurofibromas, (E,F) gliomas, (G) scoliosis, (H) pseudoarthrosis. Images are used with patient permission.

and complex gene, which carries more than $280 \mathrm{~kb}$ of genomic DNA, including 57 constitutive exons and other alternative spliced exons (9). The overall pathological NF1 mutation rate is $92.1 \%(70 / 76)$ in NF1 individuals detected by next-generation sequencing (10). Till now, over 2,800 different NF1 variants have been identified (11). Certain genotype-phenotype correlations have been identified, although most mutations are inactivating. That cannot simply answer the variable expressivity, as more severe manifestations can be observed in siblings even with the same germline mutation in NF1 families and vice versa (12). This indicates that modifier genes may play a vital role for the differences in clinical manifestation besides genotype-phenotype correlation $(11,13)$. Theoretically, modifiers themselves do not have clinically pathogenic features, but they affect target genes which related to a certain genetic disease and modulate phenotypic manifestations (14-17). Identification of NF1 genotype-phenotype correlations and genetic modifiers is

\footnotetext{
Abbreviations: NF1, neurofibromatosis type 1; CALMs, cafe-au-lait macules; CNFs, cutaneous neurofibromas; PNFs, plexiform neurofibromas; MPNST, malignant peripheral nerve sheath tumor; SCPs, Schwann cell precursors; ANFs, atypical neurofibromas; ANNUBPs, atypical neurofibromatous neoplasms of uncertain biologic potential; VDR, vitamin D receptor; RNF, ring finger protein; ADCY adenylate cyclase; OPG, optic glioma.
}

pivotal to understanding the underlying molecular mechanisms of pathogenesis, progression, and expressive variety in NF1.

This review outlines the current studies of NF1 genetic heterogeneity and modifier genes in NF1. The differences in the mutations of NF1 gene and related modifiers are described according to variable phenotypes (summarized in Table 1). Understanding their correlation will help for earlier diagnosis, probable target-driven therapies, and prognostic prediction of NF1 patients.

\section{MUTATIONS OF NF1 OR MODIFIER GENES RELATED TO DIFFERENT NF1 PHENOTYPES}

\section{Clinical NF1-Related Manifestations Pigmentary Features}

CALMs are regarded as the most common pigmentary feature of NF1 caused by biallelic loss of NF1 in melanocytes (54). They can be detected in $2.7 \%$ of newborns and $28 \%$ of young children (55). These macules also are the earliest manifestation of NF1, with great diagnostic importance in younger children. They may have a higher risk for NF1, which could be warranted later by other features (55). 
TABLE 1 | A list of mutations of NF1 gene and genetic modifiers that related to different NF1 phenotypes involved in this article.

\begin{tabular}{|c|c|c|c|}
\hline Phenotypes & NF1 gene mutations & Characteristics & References \\
\hline \multicolumn{4}{|l|}{ Cafe-au-lait macules } \\
\hline \multirow[t]{3}{*}{ NF1 gene mutations } & 992p.Met992del & Extinct CALMs and absence of neurofibroma & $(18)$ \\
\hline & p.Arg1809 substitution & Extinct CALMs and absence of neurofibroma & (19) \\
\hline & p.Arg1038Gly & Extinct CALMs and absence of neurofibroma & $(20)$ \\
\hline \multicolumn{4}{|l|}{ Lisch nodules } \\
\hline NF1 gene mutations & Frameshift & - & $(20-22)$ \\
\hline \multicolumn{4}{|l|}{ Cutaneous neurofibromas } \\
\hline \multirow[t]{2}{*}{ NF1 gene mutations } & $\begin{array}{l}\text { p.Met992del, } \\
\text { p.Arg1809 substitution and p.Arg1038Gly }\end{array}$ & $\begin{array}{l}\text { Mild phenotype with CALMs and absence of other types } \\
\text { of neurofibromas }\end{array}$ & $(18-20)$ \\
\hline & Microdeletions & Higher number of CNFs & $(23-25)$ \\
\hline \multicolumn{4}{|l|}{ Plexiform neurofibromas } \\
\hline $\begin{array}{l}\text { NF1 gene mutations } \\
\text { Modifier genes }\end{array}$ & $\begin{array}{l}\text { Microdeletions } \\
\text { Runx1 } \\
\text { ANRIL } \\
\text { SUZ12 } \\
\text { ATM }\end{array}$ & $\begin{array}{l}\text { High PNFs burden ( }>3,000 \mathrm{ml} \text { ) } \\
\text { Tumor-suppressor gene or oncogene } \\
\text { PNF number and malignant progression } \\
\text { PNF formation and progression } \\
\text { Initiate PNF formation and increase tumor number }\end{array}$ & $\begin{array}{l}(26) \\
(27) \\
(28) \\
(29) \\
(15)\end{array}$ \\
\hline \multicolumn{4}{|l|}{ Cognitive disorders } \\
\hline \multirow[t]{2}{*}{ NF1 gene mutations } & Exon 23a & $\begin{array}{l}\text { Hippocampal learning disability, cognitive impairment, } \\
\text { and others }\end{array}$ & $(30,31)$ \\
\hline & Exon $9 a$ & Synaptic plasticity and learning behavior & $(32)$ \\
\hline \multirow[t]{2}{*}{ Modifier genes } & Nmdar I & $\begin{array}{l}\text { Hippocampal mediated learning, memory, and spatial } \\
\text { learning }\end{array}$ & (33) \\
\hline & Rabs, synaptotagmins, CaMKII, and CREB1 & Synaptic plasticity & $(34)$ \\
\hline \multicolumn{4}{|l|}{ Osseous lesions } \\
\hline Modifier genes & $\begin{array}{l}\text { ATF4 } \\
\text { serum 25(OH) vitamin D/NDR }\end{array}$ & $\begin{array}{l}\text { Enhance skeletal development } \\
\text { Regulation of calcium homeostasis and bone mass }\end{array}$ & $\begin{array}{c}(35) \\
(36,37)\end{array}$ \\
\hline \multicolumn{4}{|l|}{ Childhood overgrowth } \\
\hline NF1 gene mutations & NF1 microdeletion in $17 q 11.2$ & Taller and heavier in young children & (3) \\
\hline $\begin{array}{l}\text { Cardiovascular malformation } \\
\text { NF1 gene mutations }\end{array}$ & $\begin{array}{l}\text { RNF135/NF1-REPa to REPb deletion } \\
\text { microdeletion }\end{array}$ & $\begin{array}{l}\text { Overgrowth syndrome } \\
\text { Cardiac anomalies }\end{array}$ & $\begin{array}{l}(38) \\
(39)\end{array}$ \\
\hline Modifier genes & $\begin{array}{l}\text { ADAP2 } \\
\text { CENTA2 and JJAZ1 }\end{array}$ & $\begin{array}{l}\text { Congenital valve defects } \\
\text { Cardiovascular malformation }\end{array}$ & $\begin{array}{l}(40) \\
(39)\end{array}$ \\
\hline \multicolumn{4}{|l|}{ Malignant peripheral nerve sheath tumor } \\
\hline $\begin{array}{l}\text { NF1 gene mutations } \\
\text { Modifier genes } \\
\text { NF1-associated optic glioma } \\
\text { NF1 gene mutations }\end{array}$ & $\begin{array}{l}\text { 844-848 Missense mutations } \\
\text { TP53/p53, CDKN2A/p16 and PTEN } \\
\text { MDM2 } \\
\text { p.R681X } \\
\text { Enrichment in the } 5^{\prime} \text { region }\end{array}$ & $\begin{array}{l}\text { Earlier PNF onset and increased risk for MPNSTs } \\
\text { Malignant development } \\
\text { Decreased survival rate } \\
\text { Increase tumor onset and optic nerve volume } \\
\text { Potential link to higher incidence of optic glioma } \\
\text { development }\end{array}$ & $\begin{array}{c}(41) \\
(42,43) \\
(44) \\
(45,46) \\
(47) \\
(5)\end{array}$ \\
\hline Modifier genes & $\begin{array}{l}\text { PTEN } \\
\text { ADCY8 }\end{array}$ & $\begin{array}{l}\text { Increased astrocyte proliferation and optic glioma growth } \\
\text { Sexually dimorphic growth in female }\end{array}$ & $\begin{array}{l}(48) \\
(49)\end{array}$ \\
\hline $\begin{array}{l}\text { Modifier genes of other non-neurofibroma } \\
\text { tumors in NF1 }\end{array}$ & $\begin{array}{l}\text { BRCA1/2 } \\
\text { MLH1 } \\
\text { ASXL1 and p19ARF }\end{array}$ & $\begin{array}{l}\text { Early-onset breast cancer } \\
\text { Early-onset leukemia } \\
\text { Development of leukemia }\end{array}$ & $\begin{array}{c}(50) \\
(51) \\
(52,53)\end{array}$ \\
\hline
\end{tabular}

Several studies have shown that certain NF1 mutations give rise to CALMs and freckling only phenotypes without any visible neurofibromas. A study of 21 unrelated NF1 probands and 26 affected relatives shows that individuals with a 3-bp loss of a single amino-acid deletion at codon 992 (p.Met992del), $0.9 \%$ frequency in NF1 mutation individuals, present a mild clinical phenotype with CALMs and absence of neurofibroma manifestations $(18,19)$. A 3-bp in-frame deletion (c.2970-2972 delAAT) in exon 17 of the NF1 gene results in the loss of one of two adjacent methionines (codon 991 or 992), which may affect the expression of the highly conserved region of neurofibromin (55). Further research on 135 individuals from 103 unrelated families with p.Met992del also confirms this result (19). Moreover, researchers identify a certain ratio of other complications including $4.8 \%$ non-optic brain tumors and $38.8 \%$ cognitive/learning disabilities in NF1 patients with this genetic change (19). Taken together, the presence of $>5$ CALMs and armpit freckling can be observed in a dramatic 166/182 (91.2\%) and 103/171 (60.2\%) cases carrying the NF1 p.Met992del pathogenic variant, according to the combined data of these two studies $(18,19)$. Even prolonging the observation period for over 9 years, neurofibroma manifestations such as CNFs 
or PNFs do not occur (19). Another study has identified that p.Arg1809 substitution, a c.5425C4T missense variant within exon 38, exhibits clinical similarities to the cohort data from the p.Met992del single amino acid deletion in $0.7 \%$ of total $786 \mathrm{NF} 1$ patients (56). This change rearranges the intradomain structure of the plekstrin homology-like domain of GTPase and confers a high predisposition to pigmentary signs without other common NF1 neurofibroma-related manifestations, such as CNFs or PNFs (56). Besides the above two, the missense variant c.3112A $>\mathrm{G}$, p.Arg1038Gly of NF1 gene, tested in seven patients from two unrelated families, is also associated with CALMs without other types of neurofibromas (57).

These genotype-phenotype correlations in NF1 have presented possible pigment-predominant tumor-free phenotypes. It is noteworthy due to the fact that CNFs are the commonest feature of NF1. More importantly, current diagnosis criteria are based on clinical symptoms, requiring multiple manifestations such as CALMs and neurofibroma for diagnosis. It is hard to fulfill the diagnosis criteria when these special NF1 mutations are present. These findings indicate that there should be future consideration of these special NF1 patients with isolated CALMs in clinical diagnosis, especially for children younger than 29 months with 6 or more CALMs (55).

Lisch nodules are another typical pigment feature in NF1 diagnosis and the most common ocular manifestation in NF1. They are benign tumors located on the iris surface and present to be well-defined, gelatinous pigments (58). Lisch nodule burden may be correlated with choroidal abnormalities in patients with NF1 (59). In a genetic study of 84 NF1 patients, including 25 siblings, 26 children, 30 parents, and 3 grandparents, the Lisch nodule phenotype presents to be more common (22.6\% vs. $9.1 \%)$ carrying frameshifting mutations (21). This result is consistent with previous observations by Sabbagh et al. (22) and Castle et al. (20).

\section{Cutaneous Neurofibromas (CNFs)}

$\mathrm{CNFs}$, also called dermal neurofibromas, exclusively grow within the cutaneous dermis layer and form hundreds or thousands of small tumors. They show no propensity to malignancy (60, 61). More than $99 \%$ of adult NF1 patients present CNFs (62). They frequently develop and increase in number from early adolescence until late adulthood (57).

Patients with three NF1 gene mutations, p.Met992del, p.Arg1809 substitution, and p.Arg1038Gly, exhibit a mild phenotype of NF1, which are associated with a lack of CNF manifestation. In an estimated $5-10 \%$ of all NF1 patients, microdeletions encompassing the entire NF1 gene and flanking regions at $17 \mathrm{q} 11.2$ are responsible for more severe features. NF1 microdeletions share the same definition with non-mosaic large NF1 deletions $(23,24)$. Patients with NF1 microdeletions are prone to a remarkably higher robust number of CNFs. In a study of Plotkin et al., 50\% (10/20) of adult patients show a very high burden of CNFs, with over 1,000 in total number (25). However, although CNFs are a relatively common feature for NF1 patients, the genetic changes specific to this phenotype are not fully understood. Identification of mutations and genotype-phenotype correlation in NF1 may better explain the tumorigenesis; physical variabilities in tumor type, density, and size; differences in growth speed of the proliferative process; or the co-occurrence of other phenotypes in CNFs.

\section{Plexiform Neurofibromas, PNFs}

Twenty to fifty percent of NF1 patients present with PNFs (63). In contrast to CNFs, PNFs have a different developmental origin and grow deeper, along internal nerve plexus cranial or large peripheral nerve sheaths. PNF is congenital and grows slowly, except for the periods of early childhood and pregnancy (64). The size and location of the tumor range determine the patients' main complaints, which include facial defects, nearby-organ compression, deformities, or invasion and may further lead to physical pain and functional damage $(65,66)$. PNFs can turn into MPNSTs, which occupied around $8-13 \%$ NF1 patients in total (67).

Extremely high PNF burden (>3,000 ml) exists significantly more frequently among NF1 patients with non-mosaic large NF1 deletions (13\% vs. $1 \%$ in patients without large NF1 deletions) $(25,26)$. Patients with higher tumor burden will in turn have a relatively higher risk to develop MPNSTs and other severe features than non-deletion NF1 patients $(25,68$, 69). As for modifiers, ANRIL is especially relevant to the PNF number (28). It affects the expression of CDKN2A/ARF and CDKN2B tumor-suppressor genes, which further interrupts the cell cycle and apoptosis in PNF and other cancers (28, 70-72). A study from Li et al. underlines the important role of Runx1, functioning paradoxically either as a tumor-suppressor gene or as a dominant oncogene in NF1 neurofibroma initiation. This overexpression of Runxl is proved in Schwann cell progenitors and neurofibromas in the classic $\mathrm{N} f \mathrm{fl} / \mathrm{fl}$; DhhCre mouse model. In this model, $\mathrm{Li}$ and colleagues confirmed that by inhibiting the expression of Runx1, the sphere number of neurofibromas reduced. The decrement of stem-like progenitor cells and cell growth can explain this change (27). Other genes (RNF43), or molecular pathways (Wnt/ $\beta$-catenin pathway), correlate with the tumorigenesis of PNFs and can also act as candidate genes $(73,74)$.

Their propensity for malignancy has been studied over the years. The expression status of ANRIL may further prompt the development of PNFs into premalignant tumors such as atypical neurofibromas (ANF) or atypical neurofibromatous neoplasms of uncertain biologic potential (ANNUBP) (75). In another cohort study, Pasmant et al. point out that SUZ12, a gene combining and inactivating ANRIL, is a modifier gene of PNF formation and progression (29). Recently, ATM is proven to be another modifier gene of NF1. It is a DNA repair-related gene, with an increased neurofibroma tumor load or malignant transformation, when overexpressed under the biallelic NF1 mutation background (15). Its heterozygosity initiates PNF formation and increases the tumor number in a Nf1-deficient mouse model by stimulating SCP self-renewal and promotion of tumorigenesis (15).

Taken together, different types of NF1 gene mutations and modifiers play an essential role in PNF tumorigenesis and tumor development. However, larger cohort individuals are still needed for verification and clarification. 


\section{Learning Disability and Other Cognitive Disorders}

Learning disabilities are one of the most frequent cognitive disorders in NF1. Up to $75 \%$ of children with NF1 have learning problems, who suffer from academic deficiency, especially in mathematics and reading $(76,77)$. Other typical cognitive disorders include motor skill impairment, attentiondeficit/hyperactivity disorder, and intellectual disability (78).

It is reported that significantly reduced expression levels of neurofibromin isoform I mRNA are correlated with a severe phenotype of NF1 features, including learning disabilities/cognitive deficit, optic gliomas, and/or neoplasm/cerebrovascular disease, by analyzing the levels of two neurofibromin isoforms in circulating leukocytes of a cohort study (31). Moreover, this finding indicates the potential role of NF1 transcript processing in modulating NF1 phenotypic severity. GEM and other animal models can also display irreplaceable roles in genetic and pharmacologic studies and provide insights into trials with high and repeatable fidelity (79). Nf1-mutant mice with certain genetic changes unveiled abnormalities and underlying mechanisms in learning and memory impairments and other behavioral deficits. Alternative splicing of exon 23a inhibits Ras-GAP functions, which is crucial for brain development and cognitive functions $(80,81)$. The lack of exon 23a in neurons specifically results in defective associative fear learning and spatial memory in mouse models $(30,31)$. Like exon 23a, the exon 9a of $N f 1$ also has a critical role in synaptic plasticity and learning behavior in the central nervous system (32). The loss of only Nf1-exon 9a in a transgenic mouse model leads to spatial learning and hippocampal plasticity deficits (32). Heterozygous null mutation of Nmdar I, a glutamate-gated ion channel, plays a critical role in hippocampal-mediated learning and memory and exacerbates the spatial learning phenotype of $\mathrm{Nf1}+/-$ mutant mice (33). This genetic modifier alters the expression of NF1-related learning impairment phenotypes (33). Other genes that may play critical roles in synaptic plasticity, including Rabs, synaptotagmins, Calcium/calmodulin-dependent protein kinase II (CaMKII), cAMP-responsive element-binding protein 1 (CREB1), oligodendrocyte-myelin glycoprotein (OMG), and Cyclin-dependent kinase 5 regulatory subunit 1 (CDK5R1), could be regarded as candidate modifier genes of cognitive disorders $(34,39)$.

\section{Osseous Lesions}

Orthopedic manifestations, including scoliosis, osteoporosis, skull defects, tibial dysplasia, and pseudarthrosis, as well as reduction in musculature strength, have been reported to affect $\sim 50 \%$ of patients with NF1 $(82,83)$. Some features may show sex predominance and are associated with other clinical NF1 phenotypes (84-86). Decreased neurofibromin on bone turnover, calcium homeostasis, and pubertal development may contribute to low bone mineralization and may further cause bony lesions (87). Identifying novel pathogenic variants in the NF1 gene helps to understand the genetic background, phenotype inclination, disease process, and therapeutic targets. This process benefits from both NF1 families and NF1-related animal models. In a recent large cohort study with 365 NF1 subjects included, wholegene deletions and frameshift variants are found correlated with skeletal abnormalities, including scoliosis and sphenoid bone dysplasia (88). From another 10 unrelated Chinese families who affected NF1 with main complaint of osseous lesions, five novel pathogenic variants including one missense variant and four frameshift variants are detected (89). As for animal models, the loss of Nf1, specifically in limb osteoprogenitor cells (Nf1 Col2 model; Nf1 Prx1 mice) or osteoblasts (Nf1 Ob2/2 model), leads to dysfunctional and malformed limbs with abnormal joint cartilages and bones (35, 90-92). These NF1-related osseous defects are linked to hyperactive TGF- $\beta 1$, RAS/ERK, JNK, and mTORC1 signaling pathways and can potentially be useful adjunctive agents for orthopedic medicine (91, 93-95).

Taken together, mutations of NF1 genes play an essential role in NF1-related osseous lesions. Moreover, other studies reveal that several factors contribute to this symptom. Modifiers including ATF4, an osteoblast-enriched transcription factor, can enhance skeletal development by increasing amino acid import and collagen synthesis in NF1-deficient osteoblasts (35). Moreover, the concentrations of serum $25(\mathrm{OH})$ vitamin $\mathrm{D}$ and its receptor (VDR), both responsible for the regulation of calcium homeostasis and bone mass, decrease and significantly correlate with higher tumor incidence in NF1 patients $(36,37)$. These related factors may contribute to osseous lesions by affecting the expression of other genes, which merits further investigation.

\section{Other Non-neoplastic Features Not Mentioned Above}

Childhood overgrowth with bone age acceleration is an unusual phenotype of NF1 resulting from a large 1.4/1.2Mb NF1 microdeletion in 17q11.2 (3). Young children with microdeletions grow taller and heavier than those without these deletions (69). In addition, both loss-of-function mutations of ring finger protein 135 (RNF135) and microdeletion of NF1$\mathrm{REPa}$ to REPb including RNF135 contribute to an overgrowth syndrome including tall stature, macrocephaly, dysmorphic features, and variable additional features in NF1 patients (38).

NF1 patients also present cardiovascular malformations. ADAP2 is a reliable candidate gene for the occurrence of congenital valve defects by affecting heart development. It has a higher incidence in NF1-microdeleted patients (40). By establishing an ADAP2 loss-of-function zebrafish model, defects in heart jogging and looping as well as defective valve development in ADAP2 morpholino oligo-injected embryos are observed (40). Moreover, CENTA2 and JJAZ1 are considered to be two possible candidates for cardiovascular malformations by analyzing clinical and genetic data from 92 NF1-microdeleted patients (39). NF1 microdeletions should be considered especially when NF1 patients sign with dysmorphisms, cardiac anomalies, and learning disability (39).

\section{NF1-Related Neoplastic Complications Malignant Peripheral Nerve Sheath Tumor, MPNST}

NF1 patients have an 8-13\% lifetime risk of developing MPNST, and $\sim 50 \%$ of MPNSTs occur due to malignant transformation from PNFs (67). Before the MPNST stage, PNFs can be further divided into ANFs and ANNUBPs by histology with multiple 
atypical features; this stage is a kind of premalignant tumor stage (75). MPNSTs significantly reduce life expectancy with no gender preference in NF1 patients (96). Meta-analyses from 1963 to 2012 indicated a worse outcome of MPNSTs in patients with NF1 syndromes compared with non-NF1 patients (97). Loss of NF1 is a necessary but not sufficient approach to the promotion of PNFs into MPNSTs. Therefore, identifying NF1 individuals predisposed to developing malignancy is of great importance.

Missense mutations affecting NF1 codons 844-848 have accelerated PNF formation at an earlier age, increased lifetime risk for MPNSTs, skeletal abnormalities, and $\sim 0.8 \%$ prevalence in unrelated NF1 patients (41). Researchers made this conclusion by constituting a cohort of 162 NF1 individuals from 129 unrelated families to evaluate the prognosis of patients with these missense mutations (41). Seventy-five percent of NF1 patients with these missense mutations are observed with severe phenotypes. Patients increase PNF incidence from 15-30 to 39\% over an observation period of more than 9 years, and the rate of malignant development to MPNSTs has reached 5\% (7/139) (41).

As for modifiers, inactivation of the TP53/p53 gene, deletion of the CDKN2A/p16 gene, and loss of PTEN are all important in the progression from low-grade neurofibroma (atypical or low-grade malignancy) to MPNST under the effect of biallelic inactivation of NF1 $(42,43,98)$. In MPNST, complete TP53 mutations are present in up to $8.2-16.9 \%$ of patients, suggesting a poor prognostic phenotype (44). Consistent with TP53, amplification of MDM2 had a prevalence of approximately $5.5 \%$ (44). Studies have shown that with either type of these two aberrations, the 5-year disease-specific survival rate would significantly decrease in NF1 patients (44). The CDKN2A/p16 gene is also important in NF1. In a study of a single patient with three different kinds of neurofibromas at the same time, a neurofibroma, a low-grade MPNST, and a high-grade MPNST, homozygous loss of the CDKN2A/p16 gene is detected in the malignant component, especially during the progression or occurrence of high-grade MPNST (42). During the malignant process, the expression level of PTEN in MPNST reduces, whose degree is dependent on the tumor stages (43). Haploinsufficiency or complete loss of PTEN may significantly accelerate PNF development as well (43).

\section{NF1-Associated Optic Glioma, OPG}

NF1 optic pathway gliomas are commonly seen in $\sim 15-20 \%$ of young children with NF1 (99). The majority of OPG patients suffer in childhood, younger than 7 years of age, and this lesion, localized within the optic pathway or brainstem, can result in unilateral proptosis, visual acuity loss, or field defects (100). It is unpredictable and requires routine surveillance.

An Nf1 non-sense mutation in exon 13, c.2041C > T (p.R681X), causes truncation of neurofibromin in an $\mathrm{Nf1}{ }^{+/-}$ engineered mouse model and leads to the development of optic gliomas with increased optic nerve volumes $(45,46)$. Enrichment of mutations in the $5^{\prime}$ region of the NF1 gene also suggests a higher incidence of optic glioma development (47). Moreover, heterozygous loss of the PTEN gene in the Nf1 mutant mouse model increases $N f 1$-deficient astrocyte proliferation and optic glioma growth (101). In contrast, from the data of another larger cohort study, no direct studies prove the genotype-phenotype correlation between the clustering mutations in the 5 region of the NF1 gene and the presence of OPG in NF1 patients (102). Further studies are needed to verify their relationship.

Studies show that some specific mutations and clinical features are more prevalent in females. For this reason, sex is considered to be a major clinical modifier of neuronal dysfunction in NF1. Sexual dimorphism exists in the cAMP pathway and especially interrupts the PDE activity, which may influence the application and efficacy of specific inhibitors for NF1 patients. The polymorphism of cAMP synthetase, adenylate cyclase 8 (ADCY8), elevates the glioma risk in NF1 female patients, but reduces it in males $(48,103)$. This sex-specific manner may be due to the ADCY8-related sexually dimorphic growth that has opposing effects on $\mathrm{Nf1}^{-/-}$astrocytes. By using the Nf1deficient mouse model, it shows that females are more prone to OPG-associated visual decrement while males were solely prevalent in spatial learning deficits (49). All these data call for a more thorough consideration with matched patient sex, when developing drugs targeting NF1-associated optic glioma or brain tumor.

\section{Other Non-neurofibroma Tumors in NF1}

Besides neurofibromas and gliomas, there have also been some reports discussing the association between NF1 and other tumors, especially those with malignant characteristics, including breast cancer or leukemia. A recent epidemiologic survey focusing on the incidence of different kinds of cancer among 8,003 NF1 patients has identified an increased risk of many individual cancers (104). Four percent of NF1 patients are diagnosed with cancer. In particular, the rates of chronic myeloid leukemia and female breast are 6.7 and $2.3 \%$, respectively, in this NF cohort (104).

Compared to healthy females, female NF1 patients have an estimated 2-fold increase in lifetime risk of breast cancer (18.0\%) (7). For NF1 females < 50 years old, the risk increases to 5 -fold that of healthy females, accompanied with more advanced stage and higher mortality (105). This means that more aggressive features of breast cancer, such as higher tumor grade, negative estrogen receptor, HER2 amplification, and inferior overall survival, are evident among female patients with NF1 compared to the age-matched population $(7,106,107)$. By using mouse models, scientists have confirmed the loss of $N f 1$ and their link to breast cancer tumorigenesis (108). However, there are limited explanations about the mechanisms underlying this phenomenon. The co-occurrence of NF1 and BRCA1/2 germline mutations may suggest a potential link to early-onset breast cancer in NF1 patients and calls for the study of more cases to obtain a convincing conclusion (50).

The association between leukemia and NF1 is controversial and needs to be further investigated. Early-onset leukemia may result from the presence of the homozygous MLH1 gene, a member of the DNA MMR genes with a concomitant NF1 gene mutation (51). The loss of ASXL1 or p19ARF can accelerate the development of leukemia in the haploinsufficient Nf1 mouse model, which may be due to the promoter 


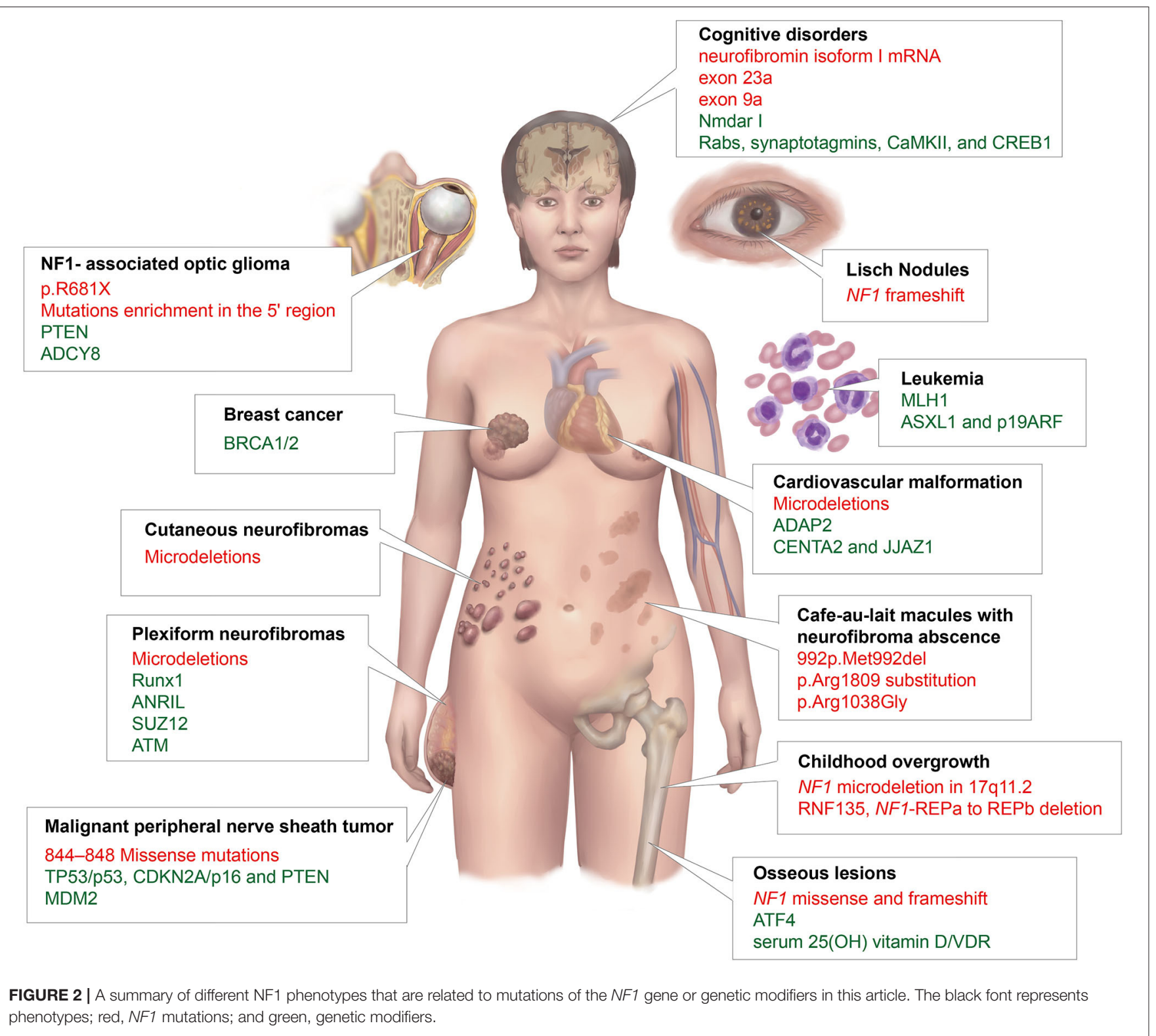

methylation or activation of the MYC and MAPK pathway, respectively $(52,53)$.

Other kinds of non-neurofibroma tumors in NF1 patients, including pheochromocytoma, astrocytoma, and gastrointestinal stromal tumors, have also been reported in several studies (109111). The c.1906G > C germline mutation in DNA mismatch repair genes that affects the expression of hMLH1, hMSH2, and hMSH6 may link to NF1 childhood malignancies (112).

We summarized and displayed the different NF1 phenotypes related to mutations of the NF1 gene or genetic modifiers that mentioned in this review in Figure 2.

\section{DISCUSSION}

NF1 shows complete genetic penetrance but variable expressivity. Although the diagnostic criteria of NF1 are well-established, the varieties of clinical phenotypes of NF1 indicate possible challenges in the diagnosis of some special patients and treatments are considered only after clinical symptoms. For example, young children with NF1 may not have enough findings to make a clinical diagnosis, especially when no positive family history exists. In this circumstance, advanced techniques for blood analysis, such as next-generation sequencing, are recommended to evaluate the potential role and mutant frequency of different genes in NF1. Moreover, genetic counseling is needed to discuss the risk for severe phenotypes or even malignancy. For instance, patients with certain NF1 mutants or suspected modifiers such as TP53 may be considered at higher risk for MPNST, which merits more careful personalized healthcare.

Other mechanisms that explain the variable phenotypes of NF1 are important, apart from NF1 gene heterogeneity 
TABLE 2 | A list of clinical trials that identify the genetic modifiers, NF1 mutations, phenotypes, or gene therapies of NF1.

\begin{tabular}{|c|c|c|c|c|}
\hline ClinicalTrials.gov ID & Study name & Recruitment status & Intervention & Phase \\
\hline NCT01650142 & Modifying Genes in Neurofibromatosis 1 & Unknown & - & - \\
\hline NCT04212351 & Frameshift Peptides of Children with NF1 & Recruiting & $\begin{array}{l}\text { Genetic: frameshift array blood } \\
\text { sample test }\end{array}$ & - \\
\hline NCT02315625 & $\begin{array}{l}\text { Study of Mutation-Targeted Therapy with Sunitinib or Everolimus in } \\
\text { People With Advanced Low- or Intermediate-Grade } \\
\text { Neuroendocrine Tumors of the Gastrointestinal Tract and } \\
\text { Pancreas With or Without Cytoreductive Surgery }\end{array}$ & Completed & Sunitinib or everolimus & $\|$ \\
\hline NCT02124772 & $\begin{array}{l}\text { Study to Investigate Safety, Pharmacokinetic (PK), } \\
\text { Pharmacodynamic (PD) and Clinical Activity of Trametinib in } \\
\text { Subjects with Cancer or Plexiform Neurofibromas and Trametinib } \\
\text { in Combination With Dabrafenib in Subjects With Cancers } \\
\text { Harboring V600 Mutations }\end{array}$ & Active, not recruiting & $\begin{array}{l}\text { Trametinib or combination with } \\
\text { dabrafenib }\end{array}$ & $|/| \mid$ \\
\hline NCT02700230 & $\begin{array}{l}\text { Vaccine Therapy in Treating Patients with Malignant Peripheral } \\
\text { Nerve Sheath Tumor That is Recurrent or Cannot Be Removed by } \\
\text { Surgery }\end{array}$ & Recruiting & $\begin{array}{l}\text { Oncolytic measles virus } \\
\text { encoding thyroidal sodium } \\
\text { iodide symporter }\end{array}$ & I \\
\hline NCT03872427 & $\begin{array}{l}\text { Testing Whether Cancers with Specific Mutations Respond Better } \\
\text { to Glutaminase Inhibitor, CB-839 HCl, Anti-Cancer Treatment, } \\
\text { BeGIN Study }\end{array}$ & Recruiting & Telaglenastat hydrochloride & $\|$ \\
\hline
\end{tabular}

and modifiers. Besides NF1-related neoplasms, they also affect sporadic or de novo tumors. These mechanisms included the following. (1) Epigenetic regulators. They affect the biochemical alterations in the development of NF1-linked tumors especially in malignant transformation process or tumor grades. For example, the epigenetic regulator polycomb repressive complex 2 (PRC2) plays an important role in malignant transformation to MPNST. The loss of PRC2 decreases dimethylation and trimethylation of $\mathrm{H} 3 \mathrm{~K} 27 \mathrm{me} 3$ production and causes epigenetic changes via EED or SUZ12 mutation. By promoting hyperactive RAS signaling and reducing immune surveillance, the loss of PRC2 contributes to the MPNST tumorigenesis $(113,114)$. Due to the frequent inactivation of PRC2, its catalytic and independent component, the enhancer of zeste homolog $2(\mathrm{EZH} 2)$, can be a potential therapy target in treating MPNST as this enhancer lacks mutation (115). Another example is glioma. It is reported that highgrade NF1 glioma exhibited frequent ATRX mutations, while a particular methylation subgroup of sporadic gliomas, the LGm6 subgroup, is enriched with ATRX mutations and assembles epigenetic profiles of NF1 glioma (116). Moreover, the epigenetic regulator can also provide a potential target when dealing with different phenotypes (117). (2) Mosaicism. It is an uncommon alteration of NF1 resulting from somatic mutations with mild and segmental presentation. Most children (65\%) present with localized pigmentary only, while older patients are prone to present with neurofibromas $(12,118)$. Other presentations can also exist. Appropriate genetic counseling is needed as gonadal mosaicism can lead to complete NF1 manifestations in offspring (119). (3) Environment, such as hormone and vitamin D (12, 120). Collectively, these observations confirmed the impact of critical epigenetic, mosaic, and environmental elements on the pathogenesis of neurofibromas or other features.

For better understanding the genetic mechanisms that underlie the different NF1-associated features, clinical trials were applied to identify the genetic modifiers involved in the variability of the clinical expression of NF1 (Clinicaltrials.gov
ID: NCT01650142), certain mutations, and phenotypes (Clinicaltrials.gov ID: NCT04212351) or evaluate the possibility of novel and genomically guided therapies (Table 2). There are several clinical trials targeted to mutate genes for NF1 patients. A completed phase II trial evaluated whether the selected drugs, sunitinib or everolimus, based on the defective gene would result in a better tumor response to patients with advanced neuroendocrine tumors, including NF1 (Clinicaltrials.gov ID: NCT02315625). Another trial studied the clinical activity of MEK1/2 inhibitors and dabrafenib combination to treat cancers especially PNFs harboring V600 mutation (Clinicaltrials.gov ID: NCT02124772). If the defective gene gets better results, it will be promising to develop gene-targeted drugs and treat NF1 patients with certain phenotypes. Another approach for application is to use vaccines that are made from a gene-modified virus in order to kill MPNST tumors that are either unresectable or recurrent with NF1 mutation (Clinicaltrials.gov ID: NCT02700230). It may also help the body build a more effective immune environment to kill tumor cells. Researchers also designed clinical trials to study the effectiveness of a glutaminase inhibitor, CB-839 HCl, in treating patients with NF1 aberrations, NF1 mutant MPNSTs, or other aberrant solid tumors (Clinicaltrials.gov ID: NCT03872427). This inhibitor works by blocking glutamine activity needed for the growth of cells and may target the uncontrolled cell growth resulting from gene mutations.

One of the major hopes for future therapies is using possible gene strategies to restore the malfunction of the NF1 gene by non-sense suppression and exon skipping to correct neurofibromin deficiency $(121,122)$. Personalized therapeutic approaches integrating genome editing technology could be used as promising and radical treatments once we fully understand the genotype-phenotype correlations and the important role of modifiers of NF1 (123). However, current studies are not enough to fully understand the genotype-phenotype correlations and heterogeneity of genes in NF1 patients. First, the role of NF1 mutants and genetic modifiers has not been well-studied 
in many other clinical features, such as skin-fold freckling or other kinds of cancers. Further clarification is needed to understand the different phenotypes. Moreover, for most of these studies, due to the insufficient size of the cohorts, the link between NF1 mutants or genetic modifiers of NF1 and phenotypic variabilities remains uncertain. More patients in multicenter studies from different countries are recommended for future research. Moreover, little research has been conducted on Chinese NF1 patients, including basic epidemiological surveys and biomedical and clinical research. Due to the heterogeneity and complexity of NF1 genotype-phenotype correlations and various genetic modifiers, detailed investigations in the Chinese population are highly needed to provide evidences for evaluating current therapies and provide future personalized medicine for Chinese NF1 patients.

\section{AUTHOR CONTRIBUTIONS}

WW, C-JW, and X-WC contributed to the conception of the study and wrote the manuscript. Y-HL and Y-HG contributed significantly to the manuscript framework and preparation.

\section{REFERENCES}

1. Le LQ, Parada LF. Tumor microenvironment and neurofibromatosis type I: connecting the GAPs. Oncogene. (2007) 26:460916. doi: 10.1038/sj.onc.1210261

2. Boyd KP, Korf BR, Theos A. Neurofibromatosis type 1. J Am Acad Dermatol. (2009) 61:1-14; quiz 15-6. doi: 10.1016/j.jaad.2008.12.051

3. Spiegel M, Oexle K, Horn D, Windt E, Buske A, Albrecht B, et al. Childhood overgrowth in patients with common NF1 microdeletions. Eur J Hum Genet. (2005) 13:883-8. doi: 10.1038/sj.ejhg.5201419

4. Reilly KM, Kim A, Blakely J, Ferner RE, Gutmann DH, Legius E, et al. Neurofibromatosis type 1-associated MPNST state of the science: outlining a research agenda for the future. J Natl Cancer Inst. (2017) 109:djx124. doi: 10.1093/jnci/djx124

5. Kaul A, Toonen JA, Cimino PJ, Gianino SM, Gutmann DH. Akt- or MEKmediated mTOR inhibition suppresses Nf1 optic glioma growth. Neuro Oncol. (2015) 17:843-53. doi: 10.1093/neuonc/nou329

6. Eisfeld AK, Kohlschmidt J, Mrózek K, Mims A, Walker CJ, Blachly JS, et al. NF1 mutations are recurrent in adult acute myeloid leukemia and confer poor outcome. Leukemia. (2018) 32:2536-45. doi: 10.1038/s41375-018-0147-4

7. Uusitalo E, Kallionpää RA, Kurki S, Rantanen M, Pitkäniemi J, Kronqvist $P$, et al. Breast cancer in neurofibromatosis type 1: overrepresentation of unfavourable prognostic factors. $\mathrm{Br} J$ Cancer. (2017) 116:211-17. doi: 10.1038/bjc.2016.403

8. Viskochil D. Genetics of neurofibromatosis 1 and the NF1 gene. J Child Neurol. (2002) 17:562-70; discussion 571-2:64651. doi: $10.1177 / 088307380201700804$

9. Gutmann DH, Wood DL, Collins FS. Identification of the neurofibromatosis type 1 gene product. Proc Natl Acad Sci USA. (1991) 88:965862. doi: 10.1073/pnas.88.21.9658

10. Maruoka R, Takenouchi T, Torii C, Shimizu A, Misu K, Higasa K, et al. The use of next-generation sequencing in molecular diagnosis of neurofibromatosis type 1: a validation study. Genet Test Mol Biomarkers. (2014) 18:722-35. doi: 10.1089/gtmb.2014.0109

11. Prasad BC, Chandra VV, Sudarsan A, Kumar PS, Sarma PV. Clinical characteristics and NF1 gene mutation analysis of three successive generations in three different Indian families with neurofibromatosis type
BG, Q-FL, and Z-CW help with the writing-review, editing, and supervision. All the authors read and approved the final manuscript.

\section{FUNDING}

This work was supported by Grants from the Youth Doctor Collaborative Innovation Team Project (QC201803) of Shanghai Ninth People's Hospital, Shanghai Jiaotong University School of Medicine; the Project of Biobank (No. YBKA201901) from Shanghai Ninth People's Hospital, Shanghai Jiao Tong University School of Medicine; the Shanghai Youth Top-Notch Talent Program (201809004), the Chenguang Program supported by Shanghai Education Development Foundation and Shanghai Municipal Education Commission (19CG18), the Science and Technology Commission of Shanghai Municipality (19JC1413), Shanghai Rising-Star Program (20QA1405600), Innovative research team of high-level local universities in Shanghai (SSMUZDCX20180700), and Shanghai Municipal Key Clinical Specialty (shslczdzk00901).
1 and peripheral nerve sheath tumours. J Clin Neurosci. (2018) 53:628. doi: 10.1016/j.jocn.2018.04.006

12. Pasmant E, Vidaud M, Vidaud D, Wolkenstein P. Neurofibromatosis type 1: from genotype to phenotype. J Med Genet. (2012) 49:4839. doi: 10.1136/jmedgenet-2012-100978

13. Riordan JD, Nadeau JH. From peas to disease: modifier genes, network resilience, and the genetics of health. Am J Hum Genet. (2017) 101:17791. doi: 10.1016/j.ajhg.2017.06.004

14. Dorfman R. Modifier gene studies to identify new therapeutic targets in cystic fibrosis. Curr Pharm Des. (2012) 18:67482. doi: $10.2174 / 138161212799315920$

15. Yu Y, Choi K, Wu J, Andreassen PR, Dexheimer PJ, Keddache M, et al. NF1 patient missense variants predict a role for ATM in modifying neurofibroma initiation. Acta Neuropathol. (2020) 139:15774. doi: 10.1007/s00401-019-02086-w

16. Debray D, Corvol H, Housset C. Modifier genes in cystic fibrosis-related liver disease. Curr Opin Gastroenterol. (2019) 35:88-92. doi: 10.1097/MOG.0000000000000508

17. Greenbaum L, Lerer B. Pharmacogenetics of antipsychotic-induced movement disorders as a resource for better understanding Parkinson's disease modifier genes. Front Neurol. (2015) 6:27. doi: 10.3389/fneur.2015.00027

18. Upadhyaya M, Huson SM, Davies M, Thomas N, Chuzhanova N, Giovannini $\mathrm{S}$, et al. An absence of cutaneous neurofibromas associated with a 3-bp inframe deletion in exon 17 of the NF1 gene (c.2970-2972 delAAT): evidence of a clinically significant NF1 genotype-phenotype correlation. Am J Hum Genet. (2007) 80:140-51. doi: 10.1086/510781

19. Koczkowska M, Callens T, Gomes A, Sharp A, Chen Y, Hicks AD, et al. Expanding the clinical phenotype of individuals with a 3-bp in-frame deletion of the NF1 gene (c.2970_2972del): an update of genotype-phenotype correlation. Genet Med. (2019) 21:867-76. doi: 10.1038/s41436-018-0269-0

20. Castle B, Baser ME, Huson SM, Cooper DN, Upadhyaya M. Evaluation of genotype-phenotype correlations in neurofibromatosis type 1. J Med Genet. (2003) 40:e109. doi: 10.1136/jmg.40.10.e109

21. Stella A, Lastella P, Loconte DC, Bukvic N, Varvara D, Patruno M, et al. Accurate Classification of NF1 Gene Variants in 84 Italian Patients with Neurofibromatosis Type 1. Genes. (2018) 9:216. doi: 10.3390/genes 9040216 
22. Sabbagh A, Pasmant E, Imbard A, Luscan A, Soares M, Blanché H, et al. NF1 molecular characterization and neurofibromatosis type I genotypephenotype correlation: the French experience. Hum Mutat. (2013) 34:15108. doi: 10.1002/humu.22392

23. Kehrer-Sawatzki H, Mautner VF, Cooper DN. Emerging genotypephenotype relationships in patients with large NF1 deletions. Hum Genet. (2017) 136:349-76. doi: 10.1007/s00439-017-1766-y

24. Bengesser K, Vogt J, Mussotter T, Mautner VF, Messiaen L, Cooper DN, et al. Analysis of crossover breakpoints yields new insights into the nature of the gene conversion events associated with large NF1 deletions mediated by nonallelic homologous recombination. Hum Mutat. (2014) 35:21526. doi: 10.1002/humu.22473

25. Mautner VF, Kluwe L, Friedrich RE, Roehl AC, Bammert S, Högel J, et al. Clinical characterisation of 29 neurofibromatosis type- 1 patients with molecularly ascertained 1.4 Mb type-1 NF1 deletions. J Med Genet. (2010) 47:623-30. doi: 10.1136/jmg.2009.075937

26. Kluwe L, Nguyen R, Vogt J, Bengesser K, Mussotter T, Friedrich RE, et al. Internal tumor burden in neurofibromatosis Type I patients with large NF1 deletions. Genes Chromosomes Cancer. (2012) 51:44751. doi: $10.1002 /$ gcc. 21931

27. Bakker AC, La Rosa S, Sherman LS, Knight P, Lee H, Pancza $\mathrm{P}$, et al. Neurofibromatosis as a gateway to better treatment for a variety of malignancies. Prog Neurobiol. (2017) 152:14965. doi: 10.1016/j.pneurobio.2016.01.004

28. Mußotter T, Kluwe L, Högel J, Nguyen R, Cooper DN, Mautner $\mathrm{VF}$, et al. Non-coding RNA ANRIL and the number of plexiform neurofibromas in patients with NF1 microdeletions. BMC Med Genet. (2012) 13:98. doi: 10.1186/1471-2350-13-98

29. Pasmant E, Sabbagh A, Masliah-Planchon J, Ortonne N, Laurendeau I, Melin L, et al. Role of noncoding RNA ANRIL in genesis of plexiform neurofibromas in neurofibromatosis type 1. J Natl Cancer Inst. (2011) 103:1713-22. doi: 10.1093/jnci/djr416

30. Costa RM, Yang T, Huynh DP, Pulst SM, Viskochil DH, Silva $\mathrm{AJ}$, et al. Learning deficits, but normal development and tumor predisposition, in mice lacking exon 23a of Nf1. Nat Genet. (2001) 27:399-405. doi: 10.1038/86898

31. Assunto A, Ferrara U, De Luca A, Pivonello C, Lombardo L, Piscitelli $A$, et al. Isoform-specific NF1 mRNA levels correlate with disease severity in Neurofibromatosis type 1. Orphanet J Rare Dis. (2019) 14:261. doi: 10.1186/s13023-019-1223-1

32. Gutmann DH, Zhang Y, Hirbe A. Developmental regulation of a neuronspecific neurofibromatosis 1 isoform. Ann Neurol. (1999) 46:777-82.

33. Silva AJ, Frankland PW, Marowitz Z, Friedman E, Lazlo G, Cioffi $\mathrm{D}$, et al. A mouse model for the learning and memory deficits associated with neurofibromatosis type I. Nat Genet. (1997) 15:2814. doi: 10.1038/ng0397-281

34. Park CS, Zhong L, Tang SJ. Aberrant expression of synaptic plasticityrelated genes in the NF1+/- mouse hippocampus. J Neurosci Res. (2009) 87:3107-19. doi: 10.1002/jnr.22134

35. Elefteriou F, Benson MD, Sowa H, Starbuck M, Liu X, Ron D, et al. ATF4 mediation of NF1 functions in osteoblast reveals a nutritional basis for congenital skeletal dysplasiae. Cell Metab. (2006) 4:44151. doi: 10.1016/j.cmet.2006.10.010

36. Lammert M, Friedman JM, Roth HJ, Friedrich RE, Kluwe L, Atkins D, et al. Vitamin D deficiency associated with number of neurofibromas in neurofibromatosis 1. J Med Genet. (2006) 43:810-3. doi: 10.1136/jmg.2006.041095

37. Kluwe L, Hagel C, Friedrich RE, Schnabel C, Schön G, Mautner V. Vitamin D receptor expression and serum 25(OH)D concentration inversely associates with burden of neurofibromas. Eur J Cancer Prev. (2019) 28:22024. doi: 10.1097/CEJ.0000000000000467

38. Brussa Reis L, Turchetto-Zolet AC, Fonini M, Ashton-Prolla P, Rosset C, et al. The role of co-deleted genes in neurofibromatosis type 1 microdeletions: an evolutive approach. Genes. (2019) 10:839. doi: 10.3390/genes10110839

39. Venturin M, Guarnieri P, Natacci F, Stabile M, Tenconi R, Clementi M, et al. Mental retardation and cardiovascular malformations in NF1 microdeleted patients point to candidate genes in 17q11.2. J Med Genet. (2004) 41:3541. doi: 10.1136/jmg.2003.014761
40. Venturin M, Carra S, Gaudenzi G, Brunelli S, Gallo GR, Moncini S, et al. ADAP2 in heart development: a candidate gene for the occurrence of cardiovascular malformations in NF1 microdeletion syndrome. J Med Genet. (2014) 51:436-43. doi: 10.1136/jmedgenet-2013-102240

41. Koczkowska M, Chen Y, Callens T, Gomes A, Sharp A, Johnson S, et al. Genotype-phenotype correlation in NF1: evidence for a more severe phenotype associated with missense mutations affecting NF1 codons 844-848. Am J Hum Genet. (2018) 102:69-87. doi: 10.1016/j.ajhg.2017. 12.001

42. Tajima S, Koda K. A neurogenic tumor containing a low-grade malignant peripheral nerve sheath tumor (MPNST) component with loss of p16 expression and homozygous deletion of CDKN2A/p16: a case report showing progression from a neurofibroma to a high-grade MPNST. Int J Clin Exp Pathol. (2015) 8:5113-20.

43. Keng VW, Rahrmann EP, Watson AL, Tschida BR, Moertel CL, Jessen WJ, et al. PTEN and NF1 inactivation in Schwann cells produces a severe phenotype in the peripheral nervous system that promotes the development and malignant progression of peripheral nerve sheath tumors. Cancer Res. (2012) 72:3405-13. doi: 10.1158/0008-5472.CAN-11-4092

44. Høland M, Kolberg M, Danielsen SA, Bjerkehagen B, Eilertsen IA, Hektoen $\mathrm{M}$, et al. Inferior survival for patients with malignant peripheral nerve sheath tumors defined by aberrant TP53. Mod Pathol. (2018) 31:1694707. doi: 10.1038/s41379-018-0074-y

45. Kocova M, Kochova E, Sukarova-Angelovska E. Optic glioma and precocious puberty in a girl with neurofibromatosis type 1 carrying an R681X mutation of NF1: case report and review of the literature. BMC Endocr Disord. (2015) 15:82. doi: 10.1186/s12902-015-0076-4

46. Toonen JA, Anastasaki C, Smithson LJ, Gianino SM, Li K, Kesterson RA, et al. NF1 germline mutation differentially dictates optic glioma formation and growth in neurofibromatosis-1. Hum Mol Genet. (2016) 25:170313. doi: $10.1093 / \mathrm{hmg} / \mathrm{ddw} 039$

47. Bolcekova A, Nemethova M, Zatkova A, Hlinkova K, Pozgayova S, Hlavata A, et al. Clustering of mutations in the 5' tertile of the NF1 gene in Slovakia patients with optic pathway glioma. Neoplasma. (2013) 60:65565. doi: 10.4149/neo_2013_084

48. Warrington NM, Sun T, Luo J, McKinstry RC, Parkin PC, Ganzhorn $\mathrm{S}$, et al. The cyclic AMP pathway is a sex-specific modifier of glioma risk in type I neurofibromatosis patients. Cancer Res. (2015) 75:1621. doi: 10.1158/0008-5472.CAN-14-1891

49. Diggs-Andrews KA, Brown JA, Gianino SM, Rubin JB, Wozniak DF, Gutmann DH. Sex Is a major determinant of neuronal dysfunction in neurofibromatosis type 1. Ann Neurol. (2014) 75:309-16. doi: 10.1002/ana.24093

50. Guran S, Safali M. A case of neurofibromatosis and breast cancer: loss of heterozygosity of NF1 in breast cancer. Cancer Genet Cytogenet. (2005) 156:86-8. doi: 10.1016/j.cancergencyto.2004.04.019

51. Alotaibi H, Ricciardone MD, Ozturk M. Homozygosity at variant MLH1 can lead to secondary mutation in NF1, neurofibromatosis type I and early onset leukemia. Mutat Res. (2008) 637:20914. doi: 10.1016/j.mrfmmm.2007.08.003

52. Zhang $\mathrm{P}$, He F, Bai J, Yamamoto S, Chen S, Zhang L, et al. Chromatin regulator Asxl1 loss and Nf1 haploinsufficiency cooperate to accelerate myeloid malignancy. J Clin Invest. (2018) 128:5383-98. doi: 10.1172/JCI121366

53. Wiesner SM, Geurts JL, Diers MD, Bergerson RJ, Hasz DE, Morgan KJ, et al. Nf1 mutant mice with p19ARF gene loss develop accelerated hematopoietic disease resembling acute leukemia with a variable phenotype. Am J Hematol. (2011) 86:579-85. doi: 10.1002/ajh.22035

54. De Schepper S, Maertens O, Callens T, Naeyaert JM, Lambert J, Messiaen L. Somatic mutation analysis in NF1 cafe au lait spots reveals two NF1 hits in the melanocytes. J Invest Dermatol. (2008) 128:10503. doi: $10.1038 /$ sj.jid.5701095

55. Ben-Shachar S, Dubov T, Toledano-Alhadef H, Mashiah J, Sprecher E, Constantini S, et al. Predicting neurofibromatosis type 1 risk among children with isolated cafe-au-lait macules. J Am Acad Dermatol. (2017) 76:1077-083 e3. doi: 10.1016/j.jaad.2017.02.027

56. Pinna V, Lanari V, Daniele P, Consoli F, Agolini E, Margiotti K, et al. p.Arg1809Cys substitution in neurofibromin is associated with a distinctive 
NF1 phenotype without neurofibromas. Eur J Hum Genet. (2015) 23:106871. doi: 10.1038/ejhg.2014.243

57. Jouhilahti EM, Peltonen S, Callens T, Jokinen E, Heape AM, Messiaen L, et al. The development of cutaneous neurofibromas. Am J Pathol. (2011) 178:500-5. doi: 10.1016/j.ajpath.2010.10.041

58. Boley S, Sloan JL, Pemov A, Stewart DR. A quantitative assessment of the burden and distribution of Lisch nodules in adults with neurofibromatosis type 1. Invest Ophthalmol Vis Sci. (2009) 50:503543. doi: $10.1167 /$ iovs.09-3650

59. Makino S, Tampo H, Arai Y, Obata H. Correlations between choroidal abnormalities, Lisch nodules, and age in patients with neurofibromatosis type 1. Clin Ophthalmol. (2014) 8:165-8. doi: 10.2147/OPTH. S56327

60. Lin AL, Gutmann DH. Advances in the treatment of neurofibromatosis-associated tumours. Nat Rev Clin Oncol. (2013) 10:616-24. doi: 10.1038/nrclinonc.2013.144

61. Chen Z, Mo J, Brosseau JP, Shipman T, Wang Y, Liao CP, et al. Spatiotemporal loss of NF1 in Schwann cell lineage leads to different types of cutaneous neurofibroma susceptible to modification by the hippo pathway. Cancer Discov. (2019) 9:114-29. doi: 10.1158/2159-8290.CD-18-0151

62. Ly KI, Blakeley JO. The diagnosis and management of neurofibromatosis type 1. Med Clin North Am. (2019) 103:103554. doi: 10.1016/j.mcna.2019.07.004

63. Gross AM, Singh G, Akshintala S, Baldwin A, Dombi E, Ukwuani S, et al. Association of plexiform neurofibroma volume changes and development of clinical morbidities in neurofibromatosis 1 . Neuro Oncol. (2018) 20:164351. doi: 10.1093/neuonc/noy067

64. Dombi E, Solomon J, Gillespie AJ, Fox E, Balis FM, Patronas $\mathrm{N}$, et al. NF1 plexiform neurofibroma growth rate by volumetric MRI: relationship to age and body weight. Neurology. (2007) 68:643-7. doi: 10.1212/01.wnl.0000250332.89420.e6

65. Prada CE, Rangwala FA, Martin LJ, Lovell AM, Saal HM, Schorry EK, et al. Pediatric plexiform neurofibromas: impact on morbidity and mortality in neurofibromatosis type 1. J Pediatr. (2012) 160:4617. doi: 10.1016/j.jpeds.2011.08.051

66. Nguyen R, Kluwe L, Fuensterer C, Kentsch M, Friedrich RE, Mautner VF, et al. Plexiform neurofibromas in children with neurofibromatosis type 1: frequency and associated clinical deficits. J Pediatr. (2011) 159:652-5 e2. doi: 10.1016/j.jpeds.2011.04.008

67. Evans DG, Baser ME, McGaughran J, Sharif S, Howard E, Moran A, et al. Malignant peripheral nerve sheath tumours in neurofibromatosis $1 . J$ Med Genet. (2002) 39:311-4. doi: 10.1136/jmg.39.5.311

68. Sharafi P, Ayter S. Possible modifier genes in the variation of neurofibromatosis type 1 clinical phenotypes. J Neurogenet. (2018) 32:65-77. doi: 10.1080/01677063.2018.1456538

69. Ning X, Farschtschi S, Jones A, Kehrer-Sawatzki H, Mautner VF, Friedman $\mathrm{JM}$, et al. Growth in neurofibromatosis 1 microdeletion patients. Clin Genet. (2016) 89:351-4. doi: 10.1111/cge.12632

70. Eyvani H, Moghaddaskho F, Kabuli M, Zekri A, Momeny M, TavakkolyBazzaz J, et al. Arsenic trioxide induces cell cycle arrest and alters DNA methylation patterns of cell cycle regulatory genes in colorectal cancer cells. Life Sci. (2016) 167:67-77. doi: 10.1016/j.lfs.2016.10.020

71. Chen J, Huang X, Tao C, Xiao T, Li X, Zeng Q, et al. Artemether attenuates the progression of non-small cell lung cancer by inducing apoptosis, cell cycle arrest and promoting cellular senescence. Biol Pharm Bull. (2019) 42:1720-25. doi: 10.1248/bpb.b19-00391

72. Meng L, Hu H, Zhi H, Liu Y, Shi F, Zhang L, et al. OCT4B regulates p53 and p16 pathway genes to prevent apoptosis of breast cancer cells. Oncol Lett. (2018) 16:522-8. doi: 10.3892/ol.2018.8607

73. Yang $\mathrm{F}, \mathrm{Xu} \mathrm{S}$, Liu R, Shi T, Li X, Li X, et al. The investigation for potential modifier genes in patients with neurofibromatosis type 1 based on next-generation sequencing. Onco Targets Ther. (2018) 11:91932. doi: $10.2147 /$ OTT.S156998

74. Wu J, Keng VW, Patmore DM, Kendall JJ, Patel AV, Jousma E, et al. Insertional mutagenesis identifies a STAT3/Arid1b/beta-catenin pathway driving neurofibroma initiation. Cell Rep. (2016) 14:197990. doi: 10.1016/j.celrep.2016.01.074
75. Carrió M, Gel B, Terribas E, Zucchiatti AC, Moliné T, Rosas I, et al. Analysis of intratumor heterogeneity in neurofibromatosis type 1 plexiform neurofibromas and neurofibromas with atypical features: correlating histological and genomic findings. Hum Mutat. (2018) 39:111225. doi: 10.1002/humu.23552

76. Krab LC, Aarsen FK, de Goede-Bolder A, Catsman-Berrevoets CE, Arts WF, Moll HA, et al. Impact of neurofibromatosis type 1 on school performance. $J$ Child Neurol. (2008) 23:1002-10. doi: 10.1177/0883073808316366

77. Chaix Y, Lauwers-Cancès V, Faure-Marie N, Gentil C, Lelong S, Schweitzer E, et al. Deficit in phonological processes: a characteristic of the neuropsychological profile of children with NF1. Child Neuropsychol. (2018) 24:558-74. doi: 10.1080/09297049.2017.1313970

78. Acosta MT, Bearden CE, Castellanos XF, Cutting L, Elgersma Y, Gioia G, et al. The Learning Disabilities Network (LeaDNet): using neurofibromatosis type 1 (NF1) as a paradigm for translational research. Am J Med Genet A. (2012) 158A:2225-32. doi: 10.1002/ajmg.a.35535

79. Rhodes SD, He Y, Smith A, Jiang L, Lu Q, Mund J, et al. Cdkn2a (Arf) loss drives NF1-associated atypical neurofibroma and malignant transformation. Hum Mol Genet. (2019) 28:2752-762. doi: 10.1093/hmg/ddz095

80. Hinman MN, Sharma A, Luo G, Lou H. Neurofibromatosis type 1 alternative splicing is a key regulator of Ras signaling in neurons. Mol Cell Biol. (2014) 34:2188-97. doi: 10.1128/MCB.00756-14

81. Nguyen HT, Hinman MN, Guo X, Sharma A, Arakawa H, Luo G, et al. Neurofibromatosis type 1 alternative splicing is a key regulator of Ras/ERK signaling and learning behaviors in mice. Hum Mol Genet. (2017) 26:3797807. doi: $10.1093 / \mathrm{hmg} / \mathrm{ddx} 264$

82. Elefteriou F, Kolanczyk M, Schindeler A, Viskochil DH, Hock JM, Schorry EK, et al. Skeletal abnormalities in neurofibromatosis type 1: approaches to therapeutic options. Am J Med Genet A. (2009) 149A:232738. doi: 10.1002/ajmg.a.33045

83. Kossler N, Stricker S, Rödelsperger C, Robinson PN, Kim J, Dietrich C, et al. Neurofibromin (Nf1) is required for skeletal muscle development. Hum Mol Genet. (2011) 20:2697-709. doi: 10.1093/hmg/ddr149

84. Visnapuu V, Peltonen S, Ellilä T, Kerosuo E, Väänänen K, Happonen RP, et al. Periapical cemental dysplasia is common in women with NF1. Eur J Med Genet. (2007) 50:274-80. doi: 10.1016/j.ejmg.2007.04.001

85. Friedrich RE, Reul A. Periapical cemento-osseous dysplasia is rarely diagnosed on orthopantomograms of patients with neurofibromatosis type 1 and is not a gender-specific feature of the disease. Anticancer Res. (2018) 38:2277-84. doi: 10.21873/anticanres.12472

86. Arrington DK, Danehy AR, Peleggi A, Proctor MR, Irons MB, Ullrich NJ. Calvarial defects and skeletal dysplasia in patients with neurofibromatosis Type 1. J Neurosurg Pediatr. (2013) 11:410-6. doi: 10.3171/2013.1.PEDS12409

87. Armstrong L, Jett K, Birch P, Kendler DL, McKay H, Tsang E, et al. The generalized bone phenotype in children with neurofibromatosis 1: a sibling matched case-control study. Am J Med Genet A. (2013) 161A:165461. doi: 10.1002/ajmg.a.36001

88. Scala M, Schiavetti I, Madia F, Chelleri C, Piccolo G, Accogli A, et al. Genotype-phenotype correlations in neurofibromatosis type 1: a singlecenter cohort study. Cancers. (2021) 13:1879. doi: 10.3390/cancers13081879

89. Chen L, Xue F, Xu J, He J, Fu W, Zhang Z, et al. Five novel NF1 gene pathogenic variants in 10 different Chinese families with neurofibromatosis type 1. Mol Genet Genomic Med. (2019) 7:e904. doi: 10.1002/mgg3.904

90. Schindeler A, Little DG. Recent insights into bone development, homeostasis, and repair in type 1 neurofibromatosis (NF1). Bone. (2008) 42:616-22. doi: 10.1016/j.bone.2007.11.006

91. Wang W, Nyman JS, Ono K, Stevenson DA, Yang X, Elefteriou F, et al. Mice lacking Nf1 in osteochondroprogenitor cells display skeletal dysplasia similar to patients with neurofibromatosis type I. Hum Mol Genet. (2011) 20:3910-24. doi: 10.1093/hmg/ddr310

92. Alanne MH, Siljamäki E, Peltonen S, Väänänen K, Windle JJ, Parada LF, et al. Phenotypic characterization of transgenic mice harboring $\mathrm{Nfl}+/$ - or Nf1-/- osteoclasts in otherwise Nf1+/+ background. J Cell Biochem. (2012) 113:2136-46. doi: 10.1002/jcb.24088

93. Rhodes SD, Wu X, He Y, Chen S, Yang H, Staser KW, et al. Hyperactive transforming growth factor-betal signaling potentiates skeletal defects in a 
neurofibromatosis type 1 mouse model. J Bone Miner Res. (2013) 28:247689. doi: 10.1002/jbmr.1992

94. Sullivan K, El-Hoss J, Little DG, Schindeler A. JNK inhibitors increase osteogenesis in Nf1-deficient cells. Bone. (2011) 49:1311-6. doi: 10.1016/j.bone.2011.09.043

95. Li Y, Li J, Zhou Q, Liu Y, Chen W, Xu H. mTORC1 signaling is essential for neurofibromatosis type I gene modulated osteogenic differentiation of BMSCs. J Cell Biochem. (2019) 120:2886-896. doi: 10.1002/jcb. 26626

96. Uusitalo E, Rantanen M, Kallionpää RA, Pöyhönen M, Leppävirta $\mathrm{J}$, Ylä-Outinen $\mathrm{H}$, et al. Distinctive cancer associations in patients with neurofibromatosis type 1. J Clin Oncol. (2016) 34:1978-86. doi: 10.1200/JCO.2015.65.3576

97. Kolberg M, Høland M, Ågesen TH, Brekke HR, Liestøl K, Hall KS, et al. Survival meta-analyses for $>1800$ malignant peripheral nerve sheath tumor patients with and without neurofibromatosis type 1. Neuro Oncol. (2013) 15:135-47. doi: 10.1093/neuonc/nos287

98. Cichowski K, Shih TS, Schmitt E, Santiago S, Reilly K, McLaughlin ME, et al. Mouse models of tumor development in neurofibromatosis type 1. Science. (1999) 286:2172-6. doi: 10.1126/science.286.5447.2172

99. Listernick R, Charrow J, Greenwald M, Mets M. Natural history of optic pathway tumors in children with neurofibromatosis type 1: a longitudinal study. J Pediatr. (1994) 125:63-6. doi: 10.1016/S0022-3476(94)70122-9

100. Campen CJ, Gutmann DH. Optic pathway gliomas in neurofibromatosis type 1. J Child Neurol. (2018) 33:73-81. doi: 10.1177/0883073817739509

101. Kaul A, Toonen JA, Gianino SM, Gutmann DH. The impact of coexisting genetic mutations on murine optic glioma biology. Neuro Oncol. (2015) 17:670-7. doi: 10.1093/neuonc/nou287

102. Hutter S, Piro RM, Waszak SM, Kehrer-Sawatzki H, Friedrich RE, Lassaletta A, et al. No correlation between NF1 mutation position and risk of optic pathway glioma in 77 unrelated NF1 patients. Hum Genet. (2016) 135:46975. doi: 10.1007/s00439-016-1646-x

103. Warrington NM, Sun T, Rubin JB. Targeting brain tumor cAMP: the case for sex-specific therapeutics. Front Pharmacol. (2015) 6:153. doi: 10.3389/fphar.2015.00153

104. Seminog OO, Goldacre MJ. Risk of benign tumours of nervous system, and of malignant neoplasms, in people with neurofibromatosis: population-based record-linkage study. Br J Cancer. (2013) 108:1938. doi: 10.1038/bjc.2012.535

105. Suarez-Kelly LP, Yu L, Kline D, Schneider EB, Agnese DM, Carson WE. Increased breast cancer risk in women with neurofibromatosis type 1: a meta-analysis and systematic review of the literature. Hered Cancer Clin Pract. (2019) 17:12. doi: 10.1186/s13053-019-0110-z

106. Evans DG, Kallionpää RA, Clementi M, Trevisson E, Mautner VF, Howell SJ, et al. Breast cancer in neurofibromatosis 1: survival and risk of contralateral breast cancer in a five country cohort study. Genet Med. (2020) 22:398406. doi: 10.1038/s41436-019-0651-6

107. Yap YS, Munusamy P, Lim C, Chan CH, Prawira A, Loke SY, et al. Breast cancer in women with neurofibromatosis type 1 (NF1): a comprehensive case series with molecular insights into its aggressive phenotype. Breast Cancer Res Treat. (2018) 171:719-35. doi: 10.1007/s10549-018-4851-6

108. Wallace MD, Pfefferle AD, Shen L, McNairn AJ, Cerami EG, Fallon $\mathrm{BL}$, et al. Comparative oncogenomics implicates the neurofibromin 1 gene (NF1) as a breast cancer driver. Genetics. (2012) 192:38596. doi: 10.1534 /genetics.112.142802

109. Gieldon L, Masjkur JR, Richter S, Därr R, Lahera M, Aust D, et al. Next-generation panel sequencing identifies NF1 germline mutations in three patients with pheochromocytoma but no clinical diagnosis of neurofibromatosis type 1. Eur J Endocrinol. (2018) 178:K1-9. doi: 10.1530/EJE-17-0714

110. Vlenterie M, Flucke U, Hofbauer LC, Timmers HJ, Gastmeier J, Aust $\mathrm{DE}$, et al. Pheochromocytoma and gastrointestinal stromal tumors in patients with neurofibromatosis type I. Am J Med. (2013) 126:17480. doi: 10.1016/j.amjmed.2012.07.022
111. Rodriguez FJ, Vizcaino MA, Blakeley J, Heaphy CM. Frequent alternative lengthening of telomeres and ATRX loss in adult NF1-associated diffuse and high-grade astrocytomas. Acta Neuropathol. (2016) 132:7613. doi: 10.1007/s00401-016-1619-0

112. Toledano H, Goldberg Y, Kedar-Barnes I, Baris H, Porat RM, Shochat C, et al. Homozygosity of MSH2 c.1906G->C germline mutation is associated with childhood colon cancer, astrocytoma and signs of Neurofibromatosis type I. Fam Cancer. (2009) 8:187-94. doi: 10.1007/s10689-008-9227-3

113. De Raedt T, Beert E, Pasmant E, Luscan A, Brems H, Ortonne N, et al. PRC2 loss amplifies Ras-driven transcription and confers sensitivity to BRD4-based therapies. Nature. (2014) 514:247-51. doi: 10.1038/nature13561

114. Zhang X, Murray B, Mo G, Shern JF. The role of polycomb repressive complex in malignant peripheral nerve sheath tumor. Genes. (2020) 11:287. doi: $10.3390 /$ genes 11030287

115. Korfhage J, Lombard DB. Malignant peripheral nerve sheath tumors: from epigenome to bedside. Mol Cancer Res. (2019) 17:1417-28. doi: 10.1158/1541-7786.MCR-19-0147

116. D’Angelo F, Ceccarelli M, Garofano L, Zhang J, Frattini V, Caruso FP, et al. The molecular landscape of glioma in patients with Neurofibromatosis 1. Nat Med. (2019) 25:176-87. doi: 10.1038/s41591-018-0263-8

117. Grit JL, Johnson BK, Dischinger PS, Essenburg CJ, Adams M, Campbell $\mathrm{S}$, et al. Distinctive epigenomic alterations in NF1-deficient cutaneous and plexiform neurofibromas drive differential MKK/p38 signaling. Epigenet Chromatin. (2021) 14:7. doi: 10.1186/s13072-020-00380-6

118. Garcia-Romero MT, Parkin P, Lara-Corrales I. Mosaic neurofibromatosis type 1: a systematic review. Pediatr Dermatol. (2016) 33:917. doi: $10.1111 /$ pde. 12673

119. Kehrer-Sawatzki H, Cooper DN. Mosaicism in sporadic neurofibromatosis type 1: variations on a theme common to other hereditary cancer syndromes? J Med Genet. (2008) 45:622-31. doi: 10.1136/jmg.2008.059329

120. Riccardi C, Perrone L, Napolitano F, Sampaolo S, Melone MA. Understanding the biological activities of vitamin $\mathrm{D}$ in type 1 neurofibromatosis: new insights into disease pathogenesis and therapeutic design. Cancers. (2020) 12:2965. doi: 10.3390/cancers121 02965

121. Keeling KM, Xue X, Gunn G, Bedwell DM. Therapeutics based on stop codon readthrough. Annu Rev Genomics Hum Genet. (2014) 15:37194. doi: 10.1146/annurev-genom-091212-153527

122. Pros E, Fernández-Rodríguez J, Canet B, Benito L, Sánchez A, Benavides A, et al. Antisense therapeutics for neurofibromatosis type 1 caused by deep intronic mutations. Hum Mutat. (2009) 30:454-62. doi: 10.1002/humu.20933

123. Walker JA, Upadhyaya M. Emerging therapeutic targets for neurofibromatosis type 1. Expert Opin Ther Targets. (2018) 22:419-37. doi: 10.1080/14728222.2018.1465931

Conflict of Interest: The authors declare that the research was conducted in the absence of any commercial or financial relationships that could be construed as a potential conflict of interest.

Publisher's Note: All claims expressed in this article are solely those of the authors and do not necessarily represent those of their affiliated organizations, or those of the publisher, the editors and the reviewers. Any product that may be evaluated in this article, or claim that may be made by its manufacturer, is not guaranteed or endorsed by the publisher.

Copyright $\odot 2021$ Wang, Wei, Cui, Li, Gu, Gu, Li and Wang. This is an open-access article distributed under the terms of the Creative Commons Attribution License (CC $B Y)$. The use, distribution or reproduction in other forums is permitted, provided the original author(s) and the copyright owner(s) are credited and that the original publication in this journal is cited, in accordance with accepted academic practice. No use, distribution or reproduction is permitted which does not comply with these terms. 